\title{
The Effect of Brand Image, Brand Personality and Brand Awareness on Purchase Intention of Local Fashion Brand "This Is April"
}

\author{
Naurah Tsabitah ${ }^{1}$ and Rila Anggraeni ${ }^{2}$ \\ 1,2 Management Department, Faculty of Economics and Business, \\ Universitas Brawijaya
}

naurahtsabitah74@gmail.com

\begin{abstract}
The fashion industry is one of the sectors in the creative economy. In 2019, the Indonesian Ministry of Industry revealed that the clothing industry recorded the largest export value. Therefore, business activists are competing to create local fashion brands and take steps to create purchase intention. This study aims to determine the impact of brand image, brand personality, and brand awareness on purchase intention Local Fashion Brand "This Is April" in Malang City. This is explanatory research type with a quantitative approach. The samples are 160 respondents. The sampling method is non-probability sampling with purposive sampling technique. The data collection method is questionnaire distributed online. This study used multiple linear regression analysis methods using IBM SPSS software. This study findings show that brand personality and brand awareness have a significant effect on purchase intention. Meanwhile, brand image has no effect on purchase intention. This study suggested that the company should maintain and increasing brand personality and brand awareness by, among others, following the fashion trends, project endorsement and collaboration with influencers to creat purchase intention.
\end{abstract}

Keywords: Brand Image, Brand Persoanlity, Brand Awareness, Purchase Intention

JEL $\quad:$ M3

DOI $\quad: 10.24002 /$ kinerja.v25i2.4701

Received : 21/07/2021 Reviewed: 31/08/2021 Final Version: 01/09/2021 


\section{INTRODUCTION}

The development of internet technology has made the shopping activities much more convenient. The online shopping is more user friendly in recent years (Lestari, 2015). The internet as a new media is believed to become a fast medium to send information and affecting everyone to fulfill their needs and desires (Nia and Loisa, 2019). One of which is shopping activities to support the appearance.

Most women very interested in an attractive appearance. Women are very concerned about their appearance and spend a lot of money, time and effort to make better appearance (Zikra and Yusra, 2016). Cloth can support the appearance of women. It became an important points to assess the women attractiveness (Setyorini, 2020)

The Industry Ministry (Kemenprin, 2019) explained that national textile and textile product (TPT) industry recorded clothing industry as the largest export. The first 3 months of 2019 showed that apparel industry production grew by $29.19 \%$ on an annual basis. Indonesia manufacturer's fashions use the data to create the local brands fashion for women.

There are several local brands from Indonesia that have sprung up. "This Is April" is one of local fashion product brands with a website-based store for women's segment. The product categories offered are tops, bottoms, outerwear, jumpsuits \& sets, bags, shoes, cosmetics and body series (This Is April, 2020). Top Brand Index Phase 2 in 2020 (Top Brand Award, 2020) showed five business fashion that goes into Top Brand for category of online fashion shop. "This Is April" brand has not yet received an award as a Top Brand in online shop fashion category. This makes "This Is April" lagging behind several other local brands. Therefore, the public purchase intention should be examined for "This Is April" product.

Purchase intention is important as a process where consumers analyze their knowledge of product, compare the product with other similar products and make decisions about the purchased product (Raza et al. 2014). A person's decision to buy a product is affected by self-concept as the part of personal factors. Fashion can create a self-concept in relation with a person perception about himself (Bon, 2015).

Consumer self - perception can be created by brand image. Several previous studies showed that brand image has a significant effect on purchase intention (Ristanto, 2016; Agmeka et al., 2019; Apriani 2019). Adversely, other studies showed brand image did not have a significant effect on purchase intention (Li, 2017).

Companies can also pay attention and giving human personality elements into company's brand. The consumer usually believes in brand personality that suits with him when difficult to assess the features of product (Vahdati and Nejad, 2016). Several previous studies showed that brand personality has a significant effect on purchase intention (Fadhillah and Rosita, 2015; Ristanto, 2016). Adversely, other studies have showed that brand personality did not have a significant effect on purchase intention (Medinna and Hasbi 2020).

Like brand image and brand personality, brand awareness also has an important role to purchase intentions consumers. The brand awareness facilitates the consumer's ability to recognize and remember brands in different situations (Tariq et 
al., 2017). Several previous studies showed that brand awareness has a significant effect on purchase intention (Ristanto, 2016; Eliasari and Sukaatmadja, 2017; Tariq et al., 2017). Based on this description, this study aims to examine the effect of Brand Image, Brand Personality, and Brand Awareness on Purchase Intention on Local Fashion Brand "This Is April" in Malang City.

\section{LITERATURE REVIEW}

\subsection{Consumer Behavior}

Consumer behavior is a dynamic interaction of affective (feeling) and cognitive (thoughts) factors, behavior and environment where humans make exchange in their lives (Peter and Olson, 2010). Kotler and Keller (2016) defined consumer behavior as the study of how individuals, groups, and organizations choose, buy, use, and dispose the goods, services, ideas, or experiences to satisfy their needs and desires.

When the amount of information reaches a certain level, consumers begin the process of assessment and evaluation, and make a purchase decision after comparison and assessment (Bhakar et al., 2013). Consumer buying behavior is guided by the final buying behavior of consumers, both individuals and households that buy goods and services for personal consumption. All of these final consumers combine to make up the consumer market (Kotler and Armstrong, 2012).

Based on the previous statement, it can be concluded that consumer behavior is the actions of a person or group starts from choosing, using, disposing of goods and services to then compared and assessed. Thus, the results of the comparison and the assessment can produce purchasing decisions for the benefit of individuals and groups. Consumer behavior is affected by several factors below:

1. Cultural factors

These consist of sub-culture and social class. Sub-culture includes nationality, religion, race, group, and geographic area. Social class is a quite homogeneous and enduring department in a society and is hierarchically structured with participants who share the samevalues, interests, and behaviors.

2. Social factors

These consist of reference groups, family and roles and status. Reference groups influence members in at least three ways: (1) by exposing individuals to new behaviors and lifestyles, (2) influencing attitudes and self-concept, and (3) creating pressures that can influence product and brand choices. Family members play a very influential main reference group consisting of: (1) family of orientation which includes parents and siblings and (2) family of procreation which includes husband, wife, and children. A person has several groups such as family, association or organization. Roles consist of activities that a person is expected to perform, thereby conferring status. 


\section{Personal factors}

These consist of age and life cycle stage, occupation and economic circumstances, personality, and self-concept, as well as lifestyle and values. Everyone has different personal characteristics that can influence their purchasing behavior and decision. Personality is a set of human psychological traits that cause relatively consistent and long-lasting responses to environmental stimuli (including purchasing behavior). Consumers will choose a brand that suits their personality. Consumer decisions are also influenced by core values, namely in the form of a belief system that underlies attitudes and behavior.

\section{Psychological factors}

These consist of person's purchase choice which is affected by motivation, perception, learning and memory. Motivation can be described as a force that can control an individual to act. Perception is the process by which a person selects, organizes, and interprets input information to create a meaningful picture. Learning includes a person's behavior that arises from experience. And memory is divided into short-term memory where the information repository is temporary and limited and long-term memory where the information repository is more permanent and basically unlimited (Kotler and Keller 2016).

\subsection{Brand}

A brand is a name, term, sign, symbol, design, or a combination of them to identify the goods or services of one or group of sellers and to differentiate them from the competitor (Kotler and Keller, 2016). The brand definition is more than just a name, term, symbol, and so on (Shimp and Andrews, 2013). A brand is anything that a particular company offers to compare with other brands in a product category. The brand also makes the promise between the company and the consumer. It is a means of defining consumer expectations and reducing risk (Kotler and Keller, 2016).

A brand distinguishes a company's goods or services from those of other competitors. Brands can ensure that buyers will get the same quality of goods or services if they buy again (Fadhillah and Rosita, 2015). Because of past experience in products and their marketing plans, consumers understand which brands meet their needs and which ones do not. Therefore, brands provide a shorthand device or means of simplification for their product decisions (Keller, 2013). In return for customer loyalty, the company promises to provide reliable and predictable positive experiences and expected benefits through its products and service (Kotler and Keller, 2016).

Kotler and Keller (2016) revealed that branding elements consists of:

1. Memorable, wich indicates how easy is it for consumers to remember and recognize brand elements and when is the right time for purchase or consumption. 
2. Meaningful, which indicates how credible a brand element is.

3. Likable, which indicates how attractive is the brand element from the aesthetic point of view.

4. Transferable, which indicates how can brand elements introduce new products in the same or different categories.

5. Adaptable, which indicates how easily the brand can adapt and can be updated.

6. Protectable, which indicates how the brand is legally protected and competitive. When a brand name becomes synonymous with another brand, the makers must retain the rights to the trademark and not allow the brand to be generic.

\subsection{Purchase Intention}

Intention is an individual component referring to their desired behavior (Fishbein et al., 1977; Riptiono, 2017). It means that intention is also related to the possibility or probability of realizing a promise or intention (Keni et al., 2019). Purchase intention is a form of consumer behavior in response to objects that indicate the consumer's desire to make a purchase (Kotler and Keller, 2016). Psychology researches show that purchase intention is a prediction of actual purchase when there is a correspondence between the dimensions of action, target, context, and time (Keller, 2013). Whenever consumers try to buy a product, they do related research and gain experience or information about the product. After gathering enough information, consumers will compare, rate, and rate the product (Wang, Cheng and Chu, 2012; Tariq et.al., 2017).

The implementation of product purchase intentions depends on various factors such as consumer willingness and interest in the product, without social pressure on consumers from others and general understanding of acceptance (Vahdati and Nejad, 2016). It means that purchase intention is a response given by consumers who are influenced by various preferences and factors to make a purchase.

Purchase intention can be identified through several indicators such as:

a. Exploratory interest, that describes the behavior of consumer who has been looking for information about the product and the positive characteristics of the product.

b. Referential interest, that describes the tendency of consumers to refer products to others. This refers to a consumer who already has a purchase intention will advise his closest people to make a purchase of the same product.

c. Transactional interest, that describes a consumer's tendency to immediately buy or own a product. This refers to consumers who already have an interest in purchasing a certain desired product. 
d. Preferential interest, that describes the behavior of a consumer who has a primary preference for the product. This preference can only be changed if something happens to the previous preference (Ferdinand, 2014).

\subsection{Hypothesis Development}

\subsubsection{Brand Image}

Brand Image is defined as beliefs, ideas, and impressions of a person to a brand (Kotler and Armstrong, 2012). In addition, brand image is a consumer's concept; it means that most of subjective phenomena and perceptions are created by consumer interpretations, both reasoned and emotional (Dobni and Zinkhan, 1990; Li, 2017). Brand image is the overall cognition of the brand, it is formed based on certain information and the brand's past experience. Brand image is a collection of brand associations that are formed and deeply rooted in consumers' minds (Fadhillah and Rosita, 2015). Consumers are accustomed to using specific brand names. Have a consistent brand image (Rangkuti, 2004).

Biel in Consuegra (2006) pointed out that three additional images can be used to describe the brand image; the image of the product/service provider or corporate; the user image; and the image of the product/service itself. Corporate image is a set of associations perceived by consumers to companies that make a product or service including popularity and credibility. The user image is a set of associations that perceived consumer to users who have experience using a product or service include personality and lifestyle. Product image is a set of associations perceived by consumers to a product or service regarding the functional benefits of the product.

However, another opinion according to Keller (2013), a positive brand image can be created through: (1) Strength of Brand Associations that explains the deeper a person thinks about product information and relates it to existing brand knowledge, the stronger the resulting brand association, (2) Favorability of Brand Associations that explains the brand associations can be a factor or situation depending on the context and vary according to what consumers want to achieve in purchasing or consumption decisions, and (3) Uniqueness of Brand Associations that explains the marketers can make explicit unique distinctions through direct comparisons with competitors. A uniqueness can be based on attributes or benefits associated with the product. When the product has a certain uniqueness, it will create a strong association in the minds of consumers. Based on above description, the hypothesis can be stated below.

$\mathrm{H} 1$ : Brand Image (X1) has an effect on purchase intention $(Y)$ for local fashion brand of "This Is April". 


\subsubsection{Brand Personality}

Brand personality is a certain mix of human nature that can be attributed to a particular brand. Consumers often choose and use the brands personality that consistent with their own self-concept, even though the adjustment may be based on consumer's ideal self-concept or based on self-concept of others (Kotler and Keller, 2009). Brand personality is very important for consumers and marketing. It can create procedures to distinguish between various brands and is the main determinant for consumer purchase intentions (Vahdati and Nejad 2016).

The combination of brands and personality tend to become more impressive and better than brands without personality. Just like humans, brands can have various personalities such as being professional or being competent (Aaker, 2008). Jennifer Aaker stated that the dimensions of brand personality are divided into five, namely sincerity, excitement, competence, sophistication, and ruggedness (Kotler and Keller, 2016). Sincerity describes an honesty, originality product, and cheerfulness. Exitement describes a unique character, full of enthusiasm, and high imagination in making differences and innovations. Competence describes product safety, convenience, ability to be reliable and trusted by consumers. Shopistication describes the characteristics of exclusiveness, prestige, and upper class. Ruggedness describes the brand characteristics that support the resistency and power of the brand. Based on above description, the hypothesis can be stated below.

$\mathrm{H}$ 2: Brand Personality $(\mathrm{X} 2)$ affects the purchase intention $(\mathrm{Y})$ for local fashion brand of "This Is April".

\subsubsection{Brand Awareness}

Brand awareness is very important to determine the brand familiarity to the public. It needs a big effort and must be done continuously in order to get maximum brand awareness. Brand awareness is the issue that appears in customer's mind when thinking of a certain product categories and easiness to remember the name (Shimp and Andrews 2013). Brand awareness is at the lowest end of brand knowledge that parameter starts from the simple brand recognition to the cognitive thinking-based approach which is based on the detail information about the brand (Mandler, 1980; Tariq et.al., 2017)

Keller (2013) also stated that brand awareness is power to track customer memory that reflects the customer's ability to recall or recognize a brand in different conditions. Consumers who have a high level of memory of brand can affect the purchase intention towards a brand. According to Yadin (2002) in Tariq et.al. (2017), the ability of a brand to reach the previously planned level of recognition is indeed a brand awareness; consumers can recognize the brand before purchasing. Brand awareness affects consumers' brand choices, consumers' purchase intention for the brands they know, and has an additional impact on brand quality considerations compared to consumers' understanding of the brand. (Macdonald and Sharp, 2000; Tariq et.al., 2017). The level of brand awareness will be explained below. 
a. Top of mind is a brand that is first mentioned by consumers or the first that appears in the consumers' mind. In other words, the brand is the main of the various brands that exist in the consumers' mind.

b. Brand recall is consumers' ability to retrieve the brand from memory when given the product category.

c. Brand recognition is a measurement of consumers' brand awareness that measured by being given a brand cue. The questions asked are assisted by mentioning the characteristics of the brand's products.

d. Unaware of brand is the lowest level in measuring brand awareness where consumers do not recognize the brand at all (Durianto et al., 2004).

Based on above description, the hypothesis can be stated below:

H3: Brand Awareness (X3) effects on the purchase intention (Y) for local fashion brand of "This Is April".

Based on previous explanation, the research concept framework is shown in Figure 1.

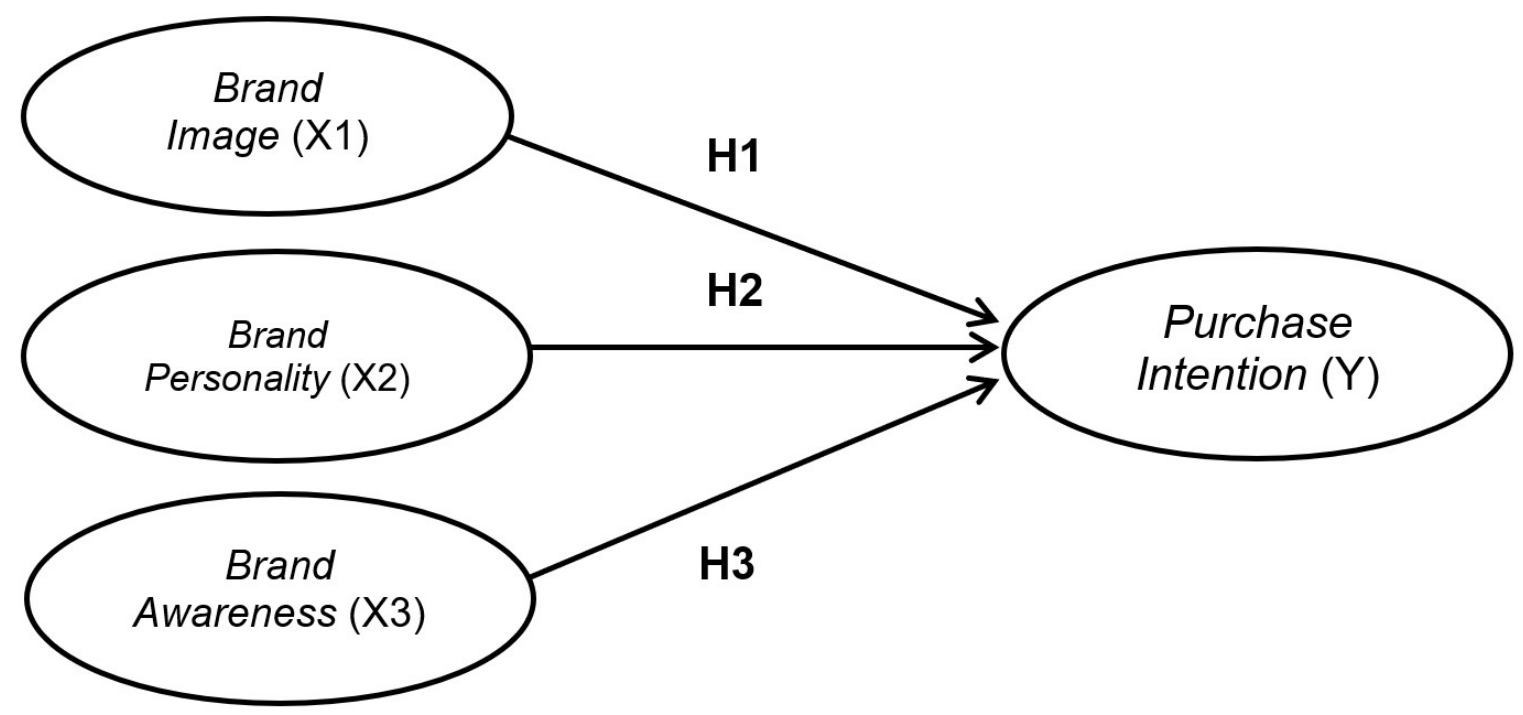

Figure 1. Research Concept Framework 


\section{METHODOLOGY}

This is explanatory research type with a quantitative approach. The population is apparel women customers in Malang City. The samples are 160 respondents. The sampling method is non-probability sampling with purposive sampling technique, with following criteria: (1) women at least 18 years old, (2) women who know the local fashion brand of "This Is April", and (3) women who have never bought products "This Is April".

The data collection method is questionnaire distributed online. The instrument test consists of: (1) validity test and (2) reliability test. The data analysis technique used multiple linear regressions with IBM SPSS software which previously tested the classical assumptions in form of: (1) normality test, (2) multicollinearity test, (3) heteroscedasticity test, and (4) linearity test. Hypothesis testing consists of goodness of fit test ( $F$ test) and partial significance test ( $t$ test).

\section{RESULT AND DISCUSSION}

\subsection{Validity Test}

Total 37 items are composed from 8 items of brand image, 13 items of brand personality, 8 items of brand awareness, and 8 items of purchase intention. There are 2 items on brand awareness that are not valid and deleted. Therefore, there are 35 items valid at with a calculated $r$ value $>r$ table.

\subsection{Reliability Test}

The results of reliability test show that all variables have a Cronbach Alpha value $>0.60$. The Cronbach Alpha of brand image is 0.835 , brand personality is 0.899 , brand awareness is 0.813 , and purchase intention is 0.857 . Therefore, all items are reliable.

\subsection{Classic Assumption Test}

The results of classical assumption test show the data follows a normal distribution and assumption of normality is met and there is no multicollinearity problem. There is no heteroscedasticity and there is a linear relationship between each independent variable and dependent variable.

\subsection{Multiple Linear Regression Analysis}

Multiple linear regression analysis aims to determine the direction of the relationship between the independent variable and the dependent variable is a positive or negative relationship. In addition, multiple linear regression analysis is also used to predict the value of the dependent variable by considering the value of the independent variable to increase or decrease (Ghozali, 2016). The results of multiple linear regression analysis are shown in Table 1 below: 
Table 1. Multiple Linear Regression Test Results

\begin{tabular}{lcc}
\hline \multirow{2}{*}{ Variable } & \multicolumn{2}{c}{ Unstandardized } \\
Coefficients \\
\cline { 2 - 3 } & B & Std. Error \\
\hline (Constant) & 1.912 & 2.711 \\
Brand image (X1) & -177 & 0.116 \\
Brand personality (X2) & 0.276 & 0.074 \\
Brand awareness (X3) & 0.754 & 0.111 \\
\hline
\end{tabular}

Source: Primary data processed, 2021

Table 1 shows the test results of multiple linear regressions. Therefore, the regression equation can be written below.

$$
\begin{gathered}
Y=a+b_{1} X_{1}+b_{2} X_{2}+b_{3} X_{3}+e \\
Y=1.912-0.177 X_{1}+0.276 X_{2}+0.754 X_{3}+e
\end{gathered}
$$

From these equations, it can be seen that:

a. The constant value (a) of 1.912 indicates that without the influence of brand image (X1), brand personality (X2), and brand awareness (X3), the value of purchase intention $(\mathrm{Y})$ is 1.912 .

b. The value of the brand image coefficient (X1) of -0.177 indicates a negative influence between brand image $(\mathrm{X} 1)$ on purchase intention $(\mathrm{Y})$. It means that every increase in the value of brand image (X1) will affect the decrease in the predicted value of purchase intention $(Y)$. This shows that the higher the brand image $(\mathrm{X} 1)$, the lower the purchase intention $(\mathrm{Y})$.

c. The value of the brand personality coefficient $(X 2)$ of 0.276 indicates a positive influence between brand personality $(\mathrm{X} 2)$ on purchase intention $(\mathrm{Y})$. It means that every increase in the value of brand personality $(X 2)$ will have an effect on increasing the predicted value of purchase intention $(Y)$. This shows that the higher the brand personality $(X 2)$, the higher the purchase intention ( $Y$ ).

d. The value of the brand awareness coefficient (X3) of 0.754 indicates a positive influence between brand awareness $(\mathrm{X} 3)$ on purchase intention $(\mathrm{Y})$. It means that every increase in the value of brand awareness (X3) will have an effect on increasing the predictive value of purchase intention $(Y)$. This shows that the higher the brand awareness $(\mathrm{X} 3)$, the higher the purchase intention $(Y)$.

\subsection{Goodness of Fit Test (F Test)}

The goodness of fit test was conducted to measure the accuracy of the sample regression function in estimating the actual value statistically. The goodness of fit model can be measured from the F statistic value. If the P-value $<0.05$ indicates that 
the $\mathrm{F}$ test is significant, so the model is feasible to be used in research (Ghozali, 2016). The Goodness of Fit test (F test) is shown in Table 2.

Table 2. Results of F Test Model

\begin{tabular}{lcrrrr}
\hline \multicolumn{1}{c}{ Model } & $\begin{array}{c}\text { Sum of } \\
\text { Squares }\end{array}$ & df & \multicolumn{1}{c}{$\begin{array}{c}\text { Mean } \\
\text { Square }\end{array}$} & F & Sig. \\
\hline Regression & 2266,164 & 3 & 755,388 & 51,528 & $.000^{\mathrm{b}}$ \\
Residual & 2286,936 & 156 & 14,660 & & \\
Total & 4553,100 & 159 & & & \\
\hline
\end{tabular}

Source: Primary data processed, 2021

Table 2 shows that $F$ arithmetic $>F$ table $(51.528>2.663)$ and a significance value of $0.000<0.050$. It means that the model has significant results and is suitable to use in this study.

\subsection{Determination Coefficient ( $R$ square)}

The determination coefficient is shown in Table 3.

Table 3. Results of Coefficient of Determination

\begin{tabular}{cccc}
\hline Model & $\mathrm{R}$ & $\mathrm{R}$ Square & $\begin{array}{c}\text { Adjusted } \mathrm{R} \\
\text { Square }\end{array}$ \\
\hline 1 & 0.705 & 0.498 & 0.488 \\
\hline
\end{tabular}

Source: Primary data processed, 2021

Table 3 shows that $R$ square value is 0.498 . This means that purchase intention variable $(Y)$ can be explained by brand image (X1), brand personality $(X 2)$, and brand awareness (X3) variables at $49.8 \%$, while the remaining $50.2 \%$ is explained by other variables outside the model.

\subsection{Partial Test ( $t$ Test)}

The t-test is needed to test the hypothesis proposed in this study. The test results are shown in Table 4.

Table 4. $t$ Test Results

\begin{tabular}{lcccc}
\hline \multicolumn{1}{c}{ Variable } & $\mathrm{t}$ count & $\mathrm{t}$ table & Sig. & Note: \\
\hline Brand Image (X1) & -1.533 & 1,975 & 0.127 & Insignificant \\
Brand Personality (X2) & 3,746 & 1,975 & 0.000 & Significant \\
Brand Awareness (X3) & 6,803 & 1,975 & 0.000 & Significant \\
\hline
\end{tabular}

Source: Primary data processed, 2021 
Based on Table 4, the following results are obtained:

a. The partial test between the brand image variable (X1) and the purchase intention variable $(\mathrm{Y})$ obtained a t count value of $1.533<$ ttable 1.975 or a significance value of $0.127>=0.05$, so it can be seen that this test proves that $\mathrm{HO}$ is accepted and $\mathrm{H} 1$ is rejected. That is, there is no significant effect between the brand image variable (X1) on the purchase intention variable $(Y)$.

b. The partial test between the brand personality variable $(\mathrm{X} 2)$ and the purchase intention variable $(\mathrm{Y})$ obtained a t count value of $3.746>$ ttable 1.975 or a significance value of $0.000<=0.05$, so it can be seen that this test proves that $\mathrm{HO}$ is rejected and $\mathrm{H} 1$ is accepted. That is, there is a significant influence between the brand personality variable $(\mathrm{X} 2)$ on the purchase intention variable $(\mathrm{Y})$.

c. The partial test between the brand awareness variable (X3) and the purchase intention variable $(Y)$ obtained a t count value of $6.803>$ ttable 1.975 or a significance value of $0.000<=0.05$, so it can be seen that this test proves that $\mathrm{HO}$ is rejected and $\mathrm{H} 1$ is accepted. That is, there is a significant influence between the brand awareness variable $(\mathrm{X} 3)$ on the purchase intention variable $(\mathrm{Y})$.

\subsection{Discussion}

\subsubsection{Effect of Brand Image on Purchase Intention}

This study results indicate that brand image variable has insignificant effect on purchase intention. This study results consistent with $\mathrm{Li}$ (2017), but inconsistent with Ristanto (2016); Agmeka, et al. (2019); Apriani (2019). This study is also unable to confirm the brand image theory proposed by Keller (2013) that to achieve a positive brand image, it needs to pay attention to: (1) Strength of Brand Associations, (2) Favorability of Brand Associations and (3) Uniqueness of Brand Associations.

There are many studies that have been conducted to determine the brand image variables that affect purchase intention. Ariely and Levav (2000) in Ahdiany (2020) argue that in front of other people, consumer choices are different from what they will make themselves. This shows that consumers think that the acquisition of a better image can be achieved through the acquisition and use of products and brands (Ahdiany, 2021). The good brand image will be perceived as good product by consumers and will attract purchase interest, and vice versa. This study shows that brand image of "This Is April" has no significant effect on purchase intention. These results indicate that although "This Is April" has a good brand image, it cannot make consumers interested to buy the brand fashion. 


\subsubsection{Effect of Brand Personality on Purchase Intention}

This study results indicate that brand personality variable has a significant effect on purchase intention. This study results consistent with Fadhillah and Rosita (2015) and Ristanto (2016), but inconsistent with Medinna and Hasbi (2020). This study results also supports the theory that creating a brand personality factors should concern to close relationship between brand personality and consumer personality (Vahdati and Nejad 2016). The average consumer perceives the brand personality of This Is April as very good and can be considered in alternative brand selection. The results of this study also explain that the higher brand personality value can make higher the purchase intention.

The consumers choose "This Is April" as a fashion product brand based on their personality matches with personality conveyed by "This Is April". The respondents agreed that "This Is April" is a brand that gives joy. It means that "This Is April" has a unique character that is full of enthusiasm and high imagination to make difference and innovation. In addition, this study also explains that "This Is April" follow the current trends. Respondents also agreed that This Is April gives a message of confidence, elegance, and durable products. Self-confidence arises when the product used is in accordance with the personality of the consumer. This is in line with This Is April's value that every woman should feel comfortable and believe in their skin and themselves. Therefore, consumers who feel comfortable with a product can stimulate purchase intention.

\subsubsection{Effect of Brand Awareness on Purchase Intention}

This study results indicate that brand awareness has a significant effect on purchase intention. These results are consistent with Ristanto (2016); Tariq et al., (2017); Eliasari and Sukaatmadja (2017). Brand awareness needs to be considered by companies that have been operating for a long time or when companies are introducing new products and services, because brand awareness can influence purchase intention in a product and service. This study results confirm the brand awareness theory that brand awareness is a determinant in consumer brand selection, consumer purchase intentions towards a brands, and subsequently has an impact on quality considerations (Macdonald and Sharp, 2000; Tariq et al., 2017).

This study results indicate that consumers often hear the "This Is April" brand as a fashion product. This brand gives consumers an alternative for consumers to choose. Although "This Is April" is not the first brand when customers want to choose fashion products, but consumers are aware that there is a "This Is April" brand that can be used as an alternative choice. In addition, This Is April also has product characteristics that consumers can easily remember, such as choosing neutral product colors and clothing models that are simple but also suitable for formal events. Therefore, brand awareness can stimulate purchase intention. 


\section{CONCLUSION}

Based on the discussion of the research results, the following conclusions are obtained:

1. "This Is April" with a good brand image does not make consumers interested to make a purchase.

2. Customers who have same personality with "This Is April" personality will have the intention to buy the brand.

3. Although "This Is April" is not a top-of-mind brand as a fashion brand, consumers realize that "This Is April" can be used as an alternative choice when they want to buy fashion products. They can have purchase interest.

\subsection{Managerial Implication}

Based on the discussion of the research results, the following managerial implications are obtained:

1. "This Is April" needs to maintain and even improve its brand personality. "This Is April" still needs to keep up with emerging fashion trends, such as maintaining the use of pastel colors that can give a cheerful and youthful impression. In addition, "This Is April" can also use ethnic motifs originating from Indonesia but designed in modern style to support "This Is April". The Indonesian ethnicity touch will provide uniqueness and create originality for "This Is April".

2. "This Is April" still needs to increase brand awareness. "This Is April" must strive to make its brand at top-of-mind awareness level to create highest level of brand awareness. "This Is April" can do endorsement activities and collaborations with public figures and influencer to make many people more remember the "This Is April" brand.

\subsection{Theoretical Implication}

This study results indicate that brand personality and brand awareness become accurate prediction of purchase intention. They have a significant effect on purchase intention. On other hand, brand image has a weak prediction on purchase intention because the brand image does not have a significant effect.

This study results show that good brand image does not always affect consumers' purchase intention in "This Is April" brand. Furthermore, brand personality contributes to create of purchase intention in "This Is April" brand. The personality of one brand has differences with other brands, as well as one's own personality. "This Is April" has an effort to maintain brand personality to become more impressive and better than brands without personality.

The brand awareness is also important to note. The brand that mentioned more often can become the main choice when customers want to buy a product. It can 
create high brand awareness. Therefore, "This Is April" as a fashion product brand needs to intensify its marketing activities to make consumers more aware.

\section{REFERENCE}

Aaker, A.D., 2008. Manajemen Ekuitas Merek. Jakarta: Mitra Utama.

Agmeka, F., Wathoni, R.N., and Santoso, A.S., 2019. The influence of Discount Framing towards Brand Reputation and Brand Image on Purchase Intention and Actual Behaviour in E-commerce. Procedia Computer Science, 161, 851-858.

Ahdiany, D.F., 2021. Pengaruh E-Wom Dan Kesadaran Merek Terhadap Minat Beli Konsumen Dengan Citra Merek Sebagai Variabel Mediasi. National Conference on Accounting \& Finance, 3, 31-41.

Apriani, M., 2019. Pengaruh Brand Image , Kualitas Produk dan Reference Group terhadap Minat Beli Produk Kosmetik Maskara Maybelline (Studi pada Mahasiswi S1 Universitas Brawijaya Malang). Jurnal IImiah Mahasiswa FEB Universitas Brawijaya, 7 (2).

Bhakar, S.S., Bhakar, S., and Bhakar, S., 2013. Relationship Between Country Of Origin, Brand Image, And Customer Purchase Intentions. Far East Journal of Psycholog and Business, 6 (9), 25-47.

Bon, C. Le, 2015. Fashion Marketing: Influencing Consumer Choice and Loyalty with Fashion Products. Business Expert Press, LLC.

Consuegra, O.I., 2006. Own labels in the United Kingdom:A source of competitive advantagein retail business. Pensamiento \& Gestión, 114, 161.

Dobni, D., \& Zinkhan, G.M., 1990. In Search of Brand Image: A Foundation Analysis. Advances in Consumer Research, 17.

Durianto, D., Sugiarto, B., and Lie, J., 2004. Brand Equity Ten, Strategi Memimpin Pasar. Jakarta: PT Gramedia Pustaka Utama.

Eliasari, P. and Sukaatmadja, I., 2017. Pengaruh Brand Awareness Terhadap Purchase Intention Dimediasi Oleh Perceived-Quality dan Brand Loyalty. E-Jurnal Manajemen Universitas Udayana, 6 (12), 248810.

Fadhillah, A.R. and Rosita, N.H., 2015. Pengaruh Brand Personality terhadap Purchase Intention dengan Brand Trust sebagai Variabel Mediasi (Studi pada Produk Running Shoes Merek Nike). Jurnal IImiah Mahasiswa FEB Universitas Brawijaya, 4 (2).

Ferdinand, A.T., 2014. Metode Penelitian Mananjemen: Pedoman Penelitian untuk Penulisan Skripsi, Tesis, dan Disertasi IImu Manajemen. Semarang: Badan Penerbit Universitas Diponegoro. 
Fishbein, M., Ajzen, I., and Hill, R.J., 1977. Belief, Attitude, Intention and Behavior: An Introduction to Theory and Research. Contemporary Sociology, 6 (2), 244.

Ghozali, I., 2016. Aplikasi Analisis Multivariete Dengan Program IBM SPSS 23. Edisi 8. Semarang: Badan Penerbit Universitas Diponegoro.

Keller, K.L., 2013. Strategic Brand Management: New Approaches to Creating and Evaluating Brand Equity. 4th ed. Pearson Education, Inc.

Kemenprin, 2019. Industri Pakaian Catatkan Perumbuhan Paling Tinggi. [online]. Available from: https://kemenperin.go.id/artikel/20641/ Industri-Pakaian-JadiCatatkan-Pertumbuhan-Paling-Tinggi . [Accessed 22 Jan 2020].

Keni, K., R, L.R.A., and Satria, A., 2019. Purchase Intention, Satisfaction, Interest, and Previous Purchase Behaviour, 5 (6).

Kotler, P. and Armstrong, G., 2012. Principles of Marketing. 14th Editi. Pearson Education.

Kotler, P. and Keller, K.L., 2009. Manajemen Pemasaran, Edisi 13, Jilid 1. Jakarta: Erlangga.

Kotler, P. and Keller, K.L., 2016. Marketing Management, 15th Edition. Pearson Education,Inc.

Lestari, S.B., 2015. Shopping Online Sebagai Gaya Hidup. Jurnal Ilmu Sosial, Vol. 14 (No. 2), 24-41.

Li, C.P., 2017. Effects of Brand Image, Perceived Price, Perceived Quality, and Perceived Value on the Purchase Intention towards Sports and Tourism Products of the 2016 Taichung International Travel Fair. The Journal of International Management Studies, 12 (2), 97-107.

Macdonald, E.K. and Sharp, B.M., 2000. Brand Awareness Effects on Consumer Decision Making for a Common, Repeat Purchase Product: A Replication. Journal of Business Research, 48, 5-15.

Medinna, G. and Hasbi, I., 2020. Pengaruh Brand Credibility, Brand Personality, dan Endorsement Beauty Vlogger Terhadap Purchase Intention dengan Brand Image Sebagai Variabel Intevening (Studi Kasus Pada Konsumen Produk Make Over Bandung). Menara Ekonomi : Penelitian dan Kajian IImiah Bidang Ekonomi, 6 (1), 37-46.

Nia, L. and Loisa, R., 2019. Pengaruh Penggunaan New Media Terhadap Pemenuhan Kebutuhan (Studi Tentang Media Sosial Facebook Dalam Pemenuhan Informasi di Kalangan Ibu Rumah Tangga). Prologia, 3 (2), 489.

Peter, J.P. and Olson, J.C., 2010. Consumer Behavior \& Marketing Strategy, Ninth Edition. McGraw-Hill/Irwin. 
Rangkuti, F., 2004. The Power of Brand. Jakarta: PT. Gramedia Pustaka Utama.

Raza, M.A., Ahad, M.A., Shafqat, M.A., Aurangzaib, M., and Rizwan, M., 2014. The Determinants of Purchase Intention towards Counterfeit Mobile Phones in Pakistan. Journal of Public Administration and Governance, 4 (3), 1.

Riptiono, S., 2017. Hasrat Konsumen yang Mengikat (Binding Customer Desires). Jurnal Fokus Bisnis, Vol.16, No (1,2), 82-92.

Ristanto, M.B.R., 2016. The Effect of Brand Origin, Brand Awareness, Brand Personality, and Brand Image Toward Purchase Intention on Local Beer Brand (Study on Potential Consumer of Beer Bintang "Radler" in Malang City. Angewandte Chemie International Edition, 6(11), 951-952.

Setyorini, T., 2020. Penelitian: Penampilan Menarik Bikin Wanita Berpotensi Dapatkan Gaji Lebih. [online]. Available from:

https://www.merdeka.com/gaya/benarkah-hobi-dandan-bisa-bikin-wanita-dapatkangaji-lebih-tinggi.html. [Accessed 16 Apr 2021].

Shimp, T.A. and Andrews, C.J., 2013. Advertising, Promotion, and Other Aspects of Integrated Marketing Communication. Integrated Marketing communications, 754.

Tariq, M., Abbas, T., Abrar, M., and Iqbal, A., 2017. EWOM and Brand Awareness Impact on Consumer Purchase Intention: Mediating Role of Brand Image. Pakistan Administrative Review, 1 (1), 84-102.

This Is April, 2020. https://www.thisisapril.com/. [online]. Available from: https://www.thisisapril.com/. [Accessed 23 Jan 2020].

Top Brand Award, 2020. Onlineshop Fashion Pakaian, Sepatu dan Aksesoris Fase 2 Tahun 2020 [online]. Available from: https://www.topbrandaward.com/en/2020/06/online-shop-fashion-pakaian-sepatu-dan-aksesoris-fase-22020/ [Accessed 19 Jan 2021].

Vahdati, H. and Nejad, S.H.M., 2016. Brand Personality toward Customer Purchase Intention: The Intermediate Role of Electronic Word-of-Mouth and Brand Equity. Asian Academy of Management Journal, 21 (2), 1-26.

Zikra, R. and Yusra, Z., 2016. Kepuasan Wanita Berbelanja Produk Fashion Berdasarkan Cara Membeli. Jurnal RAP UNP, 7 (1), 55-66. 